\title{
Faecal diversion for Crohn's colitis: a model to study the role of the faecal stream in the inflammatory process
}

\author{
M C Winslet, A Allan, V Poxon, D Youngs, M R B Keighley
}

Academic Department of Surgery, Queen Elizabeth Hospital, Birmingham M C Winslet

A Allan

V Poxon

D Youngs

M R B Keighley

Correspondence to: Mr M C Winslet, University Department of Surgery, Royal Free Hospital, London NW3 2 QG

Accepted for publication 16 June 1993

\begin{abstract}
The high incidence of clinical remission after faecal diversion for Crohn's colitis suggests the faecal stream may play a part in the inflammatory mechanism. The effect of faecal diversion $(n=22)$ and restoration of intestinal continuity $(n=10)$ was assessed in patients with Crohn's colitis and compared with controls. Faecal diversion produced significant improvement in the disease activity index mean (SEM) (before 176 (9); after 114 (9), $\mathbf{p}<0.01$ ) and serum albumin concentrations (before $33(3.0)$; after $38(3.0), p<0.05)$ in all patients with Crohn's colitis. The crypt cell production rate (CCPR) was maintained after faecal diversion for Crohn's colitis but fell in the control group (before $=3.6(0.8)$ ), at two $(1.4(0.4), \mathrm{p}<0.02)$, and six weeks $(1.6(0.4)$, $\mathbf{p}<0.05)$. Mucosal glucosamine synthetase activity, reflecting glycoprotein synthesis, was significantly lower in patients with Crohn's colitis (analysis of variance $p<0.05$ ) after diversion but was maintained in the control group. Restoration of intestinal continuity failed to produce reciprocal changes. The sustained cellular proliferation and fall in glycoprotein synthesis in Crohn's colitis after faecal diversion may represent the end of an exaggerated protective response and regenerative hyperplasia after exclusion of the faecal stream. This study suggests the faecal stream may participate in the inflammatory process in Crohn's colitis. The underlying mechanism is unknown.
\end{abstract}

(Gut 1994; 35: 236-242)

TABLE I Details of the control group receiving faecal diversion and restoration of intestinal continuity

\begin{tabular}{|c|c|c|}
\hline Indication & Previous surgery & Synchronous surgery \\
\hline \multicolumn{3}{|l|}{ Faecal diversion } \\
\hline Incontinence & \multirow{6}{*}{ Subtotal colectomy } & Loop ileostomy \\
\hline Hirschsprung's disease & & Loop ileostomy \\
\hline Sigmoid carcinoma & & Hartmann's procedure \\
\hline Incontinence & & Loop ileostomy \\
\hline Incontinence & & Loop ileostomy \\
\hline Sigmoid carcinoma & & Sigmoid colectomy/loop ileostomy \\
\hline High fistula in ano & \multirow{7}{*}{ Subtotal colectomy } & Loop colostomy \\
\hline Slow transit constipation & & Loop ileostomy \\
\hline Incontinence & & Loop ileostomy \\
\hline Incontinence & & Loop colostomy \\
\hline Incontinence & & Loop colostomy \\
\hline High fistula in ano & & Loop colostomy \\
\hline Sigmoid carcinoma & & Sigmoid colectomy/loop ileostomy \\
\hline \multicolumn{3}{|c|}{ Restoration of intestinal continuity } \\
\hline Sigmoid carcinoma & \multicolumn{2}{|c|}{ Sigmoid colectomy/loop ileostomy } \\
\hline Diverticular disease & \multirow{2}{*}{\multicolumn{2}{|c|}{ Hartmann's procedure }} \\
\hline Solitary rectal ulcer & \multirow{2}{*}{\multicolumn{2}{|c|}{ Rectopexy/loop ileostomy }} \\
\hline Enterocutaneous fistula & & \\
\hline Diverticular disease & \multicolumn{2}{|c|}{ Hartmann's procedure } \\
\hline Sigmoid carcinoma & \multicolumn{2}{|c|}{ Sigmoid colectomy/loop ileostomy } \\
\hline High fistula in ano & \multicolumn{2}{|c|}{ Loop ileostomy } \\
\hline Incontinence & \multicolumn{2}{|l|}{ Loop ileostomy } \\
\hline
\end{tabular}

The management of Crohn's colitis by external faecal diversion provides not only a therapeutic alternative to resection in selected cases $^{1-4}$ but also a unique model to evaluate the role of the faecal stream in the pathogenesis of Crohn's disease.

There are both clinical and laboratory data to implicate a constituent of the faecal stream in perpetuating colonic Crohn's disease. The use of elemental diets has been associated with disease remission. ${ }^{56}$ Simple faecal diversion is also associated with symptomatic relief $^{2-7-10}$ with a high incidence of disease relapse on restoration of intestinal continuity ${ }^{127-11}$ A luminal constituent may also be implicated from the finding that improvement in perianal disease may be induced by metronidazole ${ }^{12-15}$ and the presence of an exaggerated proliferative response by tissue lymphocytes to gut related bacterial antigens. ${ }^{16}$

The faecal stream has also been implicated in small bowel disease recurrence. Rutgeerts et $a l^{17}$ described five patients having ileocolonic resection with a proximal diverting ileostomy who only developed recurrence in the neoterminal ileum after restoration'of intestinal continuity. The authors concluded that recurrence is faecal stream dependant with the reflux of colonic contents probably important. Metronidazole has also been reported to reduce the incidence of endoscopic recurrence after surgery and significantly reduce its severity. ${ }^{18}$

Only one previous study to evaluate the role of the faecal stream in Crohn's colitis has been reported. ${ }^{1920}$ The reintroduction of crude ileostomy effluent into the defunctioned colon of patients with Crohn's colitis treated by a split ileostomy produced a clinical response in nine of 15 patients studied, associated with a significant lymphopaenia and increase in erythrocyte sedimentation rate, while the reintroduction of a sterile ultrafiltrate failed to produce any objective change.

The aim of this study was to assess the effect of faecal diversion and restoration of intestinal continuity on colonic mucosa and peripheral blood activity indices in patients with Crohn's colitis compared with a control group with macroscopically normal colonic mucosa. The influence of disease activity on peripheral blood indices was assessed by measurement of a modified disease activity index, haematological indices, serum albumin, acute phase protein, and immunoglobulin concentrations. Changes in mucosal inflammation were assessed by recording the macroscopic and microscopic appearance of the rectum and measuring colonic cellular proliferation and glycoprotein synthesis. 
TABLE II Details of patients with Crohn's colitis receiving faecal diversion and restoration of intestinal continuity

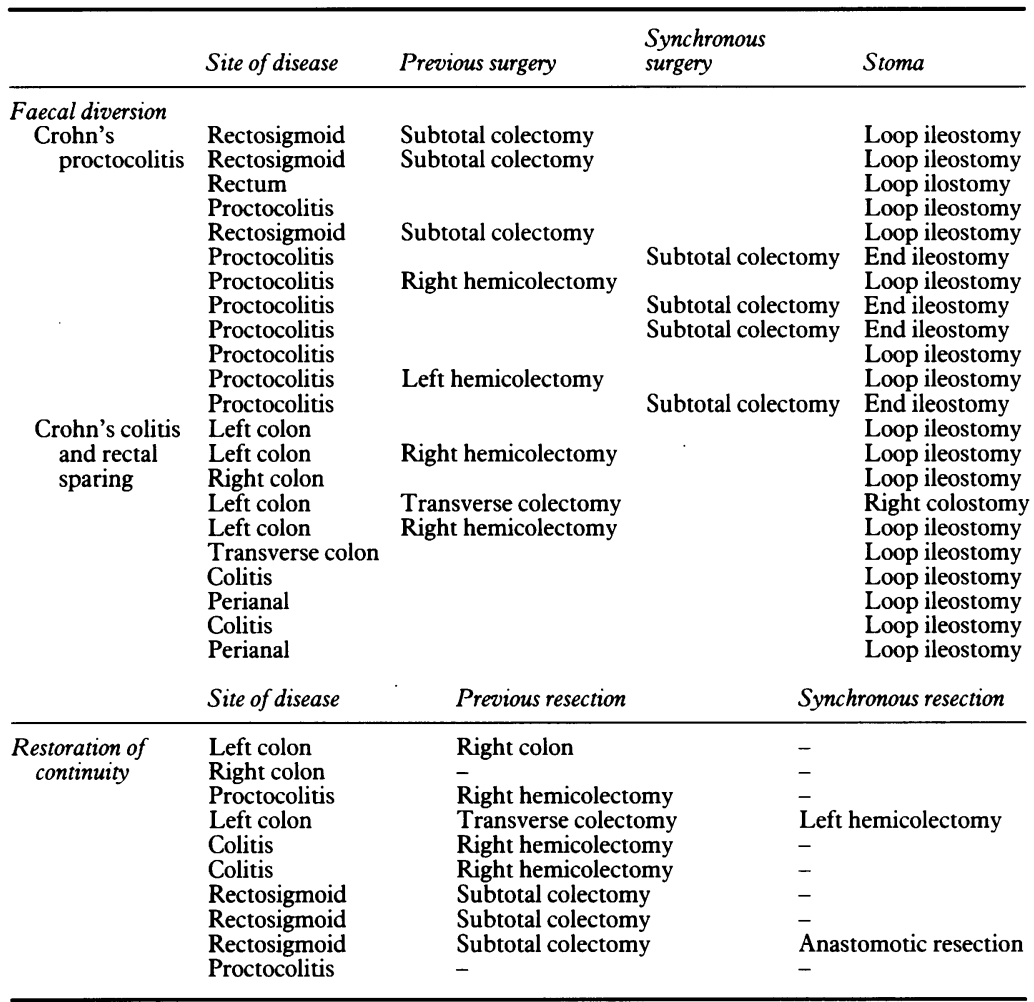

\section{Patients and methods}

\section{PATIENTS}

All patients (Tables I and II) entered the study after written informed consent and were evaluated before faecal diversion and at two, six, and 12 weeks later. Patients with Crohn's colitis were subdivided according to the macroscopic state of the rectum: proctocolitis $(n=12)$, normal rectum $(n=10)$. All patients stopped treatment for two weeks before assessment. The control group consisted of 13 patients having faecal diversion who had a macroscopically normal rectum and no evidence of inflammatory bowel disease.

Two groups of patients were studied at the same time points after restoring intestinal continuity. Patients with defunctioned Crohn's colitis $(n=10)$ and controls $(n=8)$, originally defunctioned for a non-inflammatory condition, were not classified by the macroscopic appearance of the rectum as the presence of superimposed defunctioned proctitis could not be excluded.

\section{METHODS}

Disease activity was assessed by a modification of the Dutch activity index ${ }^{21}$ reported by Pettit $e t$ $a l^{22}$ to make allowance for previous extensive resections and stomas.

Haematological indices were measured on an S-plus Coulter counter. The differential white cell count was assessed using the Romanowsky stain and the erythrocyte sedimentation rate was evaluated by the Westergreen method. Serum IgG, IgA, and IgM concentrations were quantitatively estimated by single radial immunodiffusion $^{23}$ using Immunoplates (Unipath,
Birmingham). Serum albumin concentrations were estimated by absorbance estimation using bromocresol purple on a multichannel analyser. $C$ reactive protein was measured by an immunoturbidimetric method ${ }^{24}$ using a Cobas Bio centrifugal analyser (Roche Diagnostics, UK). $\alpha_{1}$ Acid glycoprotein, $\alpha_{2}$ macroglobulin, and $\alpha_{1}$ antichymotrypsin were assessed by radial immunodiffusion using Nor-Partigen and M-Partigen plates (Behringwerke) respectively.

The macroscopic and histological state of the rectum was assessed by one observer using a standard score ${ }^{25}$ at a reference point $10 \mathrm{~cm}$ from the posterior anal verge.

Colonic cellular proliferation was assessed by an in vitro stathmokinetic technique with vincristine to induce metaphase arrest. ${ }^{26}$ Rectal biopsy specimens, taken $10 \mathrm{~cm}$ from the anal verge, were placed in organ culture dishes (Becton-Dickinson, England) semisubmerged, on wire grids (Industrial Wire Products, USA), in organ culture medium RPMI 1640 (Gibco Ltd) containing $10 \%$ fetal calf serum, penicillin $(100 \mathrm{IU} / \mathrm{ml})$ and gentamicin $(40 \mu \mathrm{g} / \mathrm{ml})$ at $37^{\circ} \mathrm{C}$, and equilibrated with $95 \% \mathrm{O}_{2}$ and $5 \% \mathrm{CO}_{2}$. After 16 hours the medium was replaced with identical medium containing vincristine sulphate $(0.5 \mu \mathrm{g} /$ $\mathrm{ml}$ ), which produces complete metaphase arrest without degeneration. Duplicate biopsy specimens were removed from dishes at 60, 100, 130, and 140 minutes, fixed in Carnoy's solution, and stained with the Fuelgen reaction. Ten individual crypts were microdissected from each biopsy specimen and the number of metaphase arrest figures counted. The mean number of metaphase arrest figures/10 crypt was plotted against time and the slope of the line was determined by linear regression analysis to give the crypt cell production rate (CCPR) in number metaphases/crypt/h.

Glycoprotein synthesis was evaluated by assessment of glucosamine synthetase activity (L-glutamine-D-fructose-6-phosphate-aminotransferease EC2.6.1.16). The glucosamine synthetase assay was performed in a manner similar to that described by Goodman, ${ }^{27}$ a modification of the method of Winterburn and Phelps. ${ }^{28}$

Rectal biopsy specimens were homogenised in fresh phosphate buffer (50 $\mathrm{mM} \quad \mathrm{NaH}_{2} \mathrm{PO}_{4}$ ) $\mathrm{Na}_{2} \mathrm{HPO}_{4}$ at $\mathrm{pH} 7$ containing $100 \mathrm{mM} \mathrm{KCl}$ and $1 \mathrm{mM}$ EDTA) and incubated at $37^{\circ} \mathrm{C}$ with $0.2 \mathrm{ml}$ of substrate buffer containing $8 \mu \mathrm{mol}$ fructose6-phosphate disodium, $3 \cdot 2 \mu \mathrm{mol}$ L-glutamine, and $40 \mu \mathrm{mol}$ gentamicin. After three hours the reaction was stopped with $10 \%$ perchloric acid. Incubates were centrifuged at $2500 \mathrm{rpm}$ for 15 minutes. Some $0.3 \mathrm{ml}$ of the supernatant was removed and the $\mathrm{pH}$ was adjusted to between 6 and 11 . Then, $0.2 \mathrm{ml}$ borate buffer $(1.12 \mathrm{~mol}$ boric acid and $0.56 \mathrm{ml} \mathrm{KOH} / \mathrm{L}, \mathrm{pH} 9.2$ ) followed by 0.05 in acetic anhydride $1.5 \% \mathrm{wt} / \mathrm{vol}$ in acetone was added to $0.2 \mathrm{ml}$ of supernatant, which was then placed in a boiling water bath for three minutes and an ice water bath for five minutes. Dimethylaminobenzaldehyde (DAB) $(1.6 \mathrm{ml})$ in glacial acetic acid containing $1.25 \mathrm{ml}$ concentrated $\mathrm{HCl}$ was added to each tube, which were then immediately placed in a water bath at $37^{\circ} \mathrm{C}$ for 20 minutes. The intensity of the 


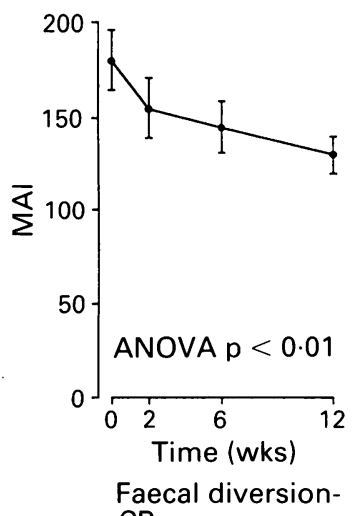
CP

Figure 1: Effect of faecal diversion and restoration of continuity on the modified disease activity index (MAI) in patients with Crohn's proctocolitis $(C P)$ and Crohn's colitis with rectal sparing (CCRS). $C D=$ Crohn's disease, $A N O V A=$ analysis of variance.

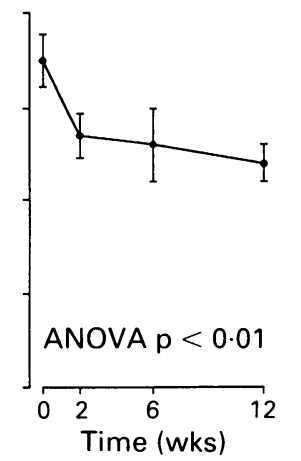

Faecal diversionCCRS

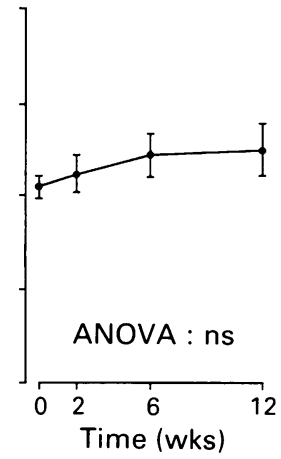

Restoration of intestinal continuity-CD purple colour formed during this, the MorganElson reaction, ${ }^{29}$ was immediately read in a spectrophotometer (Unicam SP500 at $545 \mathrm{~nm}$ ) against standard solutions of glucosamine hydrochloride $(0.05-0.3 \mathrm{mM})$.

\section{STATISTICAL ANALYSIS}

All data were evaluated by non-parametric means unless a normal distribution was shown. The change in indices within groups and between groups with time was assessed by a one way analysis of variance and by a balanced two factor hierarchical classification respectively.

\section{Results}

Faecal diversion produced a significant reduction in the modified activity index in both groups of patients with Crohn's colitis (Fig 1). The restoration of intestinal continuity in patients with defunctioned Crohn's colitis did not produce a significant increase in the activity index (Fig 1).

\section{HAEMATOLOGICAL INDICES}

The preoperative haemoglobin, total, and differential white cell count was similar in all groups, while the preoperative platelet counts and the erythrocyte sedimentation rate were significantly increased in both groups with Crohn's colitis receiving faecal diversion (Table III). Values were not significantly influenced by faecal diversion or restoration of continuity.

The preoperative values of $\operatorname{IgA}$ and $\operatorname{IgM}$ were significantly raised in patients with Crohn's colitis receiving diversion (Table III) but there was no significant change after diversion of restoration of continuity.

TABLE III Preoperative platelet count, erythrocyte sedimentation rate $(E S R)$, and immunoglobulin concentrations in patients with Crohn's colitis and controls

\begin{tabular}{llcc}
\hline & $\begin{array}{l}\text { Control } \\
\text { group }\end{array}$ & $\begin{array}{l}\text { Crohn's colitis } \\
\text { and rectal sparing }\end{array}$ & $\begin{array}{l}\text { Crohn's } \\
\text { proctocolitis }\end{array}$ \\
\hline Platelet count $\left(\times 10^{9} / 1\right)$ & $297(114)^{\star} \dagger$ & $493(131)^{\star}$ & $558(130) \dagger$ \\
ESR $(\mathrm{mm} /$ in first hour $)$ & $12(3) \dagger$ & $54(53) \dagger$ & $52(33) \dagger$ \\
$\operatorname{IgA}(\mathrm{g} / \mathrm{l})$ & $2 \cdot 0(0 \cdot 4)$ & $3 \cdot 3(0 \cdot 6)$ & $3 \cdot 7(0 \cdot 8) \Uparrow$ \\
$\operatorname{IgM}(\mathrm{g} / \mathrm{l})$ & $3 \cdot 6(0 \cdot 8) \|$ & $4 \cdot 5(1 \cdot 1)$ & $6 \cdot 9(0 \cdot 8) \|$ \\
$\operatorname{IgG}(\mathrm{g} / \mathrm{l})$ & $13 \cdot 2(2 \cdot 6)$ & $13 \cdot 7(1 \cdot 1)$ & $17 \cdot 9(2 \cdot 6)$ \\
\hline
\end{tabular}

${ }^{\star} \mathrm{p}<0.01$ unpaired $t$ test; $\nmid \mathrm{p}<0.05$ unpaired $t$ test; $\neq \mathrm{p}<0.02$ unpaired $t$ test;

$\S \mathrm{p}<0.05$ Mann-Whitney U test; $\| \mathrm{p}<0.01$ Mann-Whitney U test; values given as mean (SEM).
ALBUMIN AND ACUTE PHASE PROTEINS

The prediversion concentrations of serum albumin were significantly reduced in both groups of patients with Crohn's colitis and rose significantly after diversion (Table IV). There was no significant change in the control group after diversion and no significant change in either group after restoration of continuity (Tables IV and V).

Prediversion concentrations of $\alpha_{1}$-acid glycoprotein were significantly increased in the group with Crohn's colitis and fell in the group with Crohn's colitis and rectal sparing after diversion. No other significant change occurred in any group after diversion or restoration of continuity (Tables IV and V).

$C$ reactive protein, $\alpha_{1}$-macroglobulin, and $\alpha_{1^{-}}$ antichymotrypsin values were similar in all groups before surgery. $\alpha_{1}$ Antichymotrypsin values fell significantly in patients with Crohn's colitis and rectal sparing after diversion. No other significant change occurred after excluding or reintroducing the faecal stream (Tables IV and V).

\section{MACROSCOPIC AND HISTOLOGICAL ASSESSMENT}

Faecal diversion was not associated with any significant overall change in the macroscopic appearance of the rectal mucosa in the control group. After three months of faecal diversion there was a significant deterioration in the macroscopic appearance in patients with Crohn's colitis and rectal sparing $(\mathrm{p}<0.05$ rank sign test) with a trend to improvement in the Crohn's proctocolitis group. Restoration of intestinal continuity was associated with a significant improvement in the macroscopic appearance of the Crohn's disease group $(\mathrm{p}<0.05)$.

Neither faecal diversion nor restoration of continuity was associated with significant changes in histological assessment of the rectum.

\section{RECTAL CELLULAR PROLIFERATION}

There was no significant difference in the preoperative rectal crypt cell production rate between the control group and patients with Crohn's colitis irrespective of the state of the rectum (Fig 2). Faecal diversion in the control group was associated with a significant transient fall in the CCPR at two and six weeks after diversion. Analysis of variance over the whole time period failed to show an overall significant change. In patients with Crohn's colitis, irrespective of the state of the rectum, there was no significant change in colonic cellular proliferation (Fig 2). Reintroduction of the faecal stream was not associated with a significant change in cellular proliferation in any group.

\section{RECTAL GLYCOPROTEIN SYNTHESIS}

There was no overall significant difference in the preoperative values of glucosamine synthetase activity between patients with Crohn's proctocolitis and the control group. When classified according to epithelial state, patients with proctocolitis and epithelial preservation had significantly increased glucosamine synthetase 
TABLE IV The influence of faecal diversion on serum albumin and acute phase protein concentrations in a control group $(C)$ and patients with Crohn's proctocolitis (CP) and Crohn's colitis with rectal sparing (CCRS)

\begin{tabular}{|c|c|c|c|c|c|c|}
\hline & \multicolumn{3}{|l|}{0 Weeks } & \multicolumn{3}{|l|}{12 Weeks } \\
\hline & $C$ & $C P$ & CCRS & $C$ & $C P$ & $C C R S$ \\
\hline $\begin{array}{l}\text { Albumin }(\mathrm{g} / \mathrm{l}) \\
\alpha_{1} \text { Acid glycoprotein }(\mathrm{g} / \mathrm{l}) \\
\text { C reactive protein }(\mathrm{g} / \mathrm{l}) \\
\alpha_{2} \text { Macroglobulin }(\mathrm{g} / \mathrm{l}) \\
\alpha_{1} \text { Antichymotrypsin }(\mathrm{g} / \mathrm{l})\end{array}$ & $\begin{array}{l}40.9(1 \cdot 8)^{\star} \dagger \\
1 \cdot 1(0 \cdot 1)^{\star} \\
5 \cdot 4(0 \cdot 4) \\
2 \cdot 6(0 \cdot 9) \\
0.7(0 \cdot 1)\end{array}$ & $\begin{array}{l}28 \cdot 6(2 \cdot 4)^{\star} \ddagger \\
1 \cdot 9(0 \cdot 2)^{\star} \\
46 \cdot 4(24) \\
2 \cdot 2(0 \cdot 3) \\
1 \cdot 2(0 \cdot 2)\end{array}$ & $\begin{array}{l}34 \cdot 4(2 \cdot 0)+\varsigma \\
1 \cdot 9(0 \cdot 2)^{\star} \\
44(18) \\
2 \cdot 0(0 \cdot 9) \\
1 \cdot 1(0 \cdot 1)^{\star}\end{array}$ & $\begin{array}{l}39 \cdot 6(0 \cdot 8) \\
1 \cdot 0(0 \cdot 1) \\
5 \cdot 0(0 \cdot 1) \\
2 \cdot 3(0 \cdot 5) \\
0 \cdot 6(0 \cdot 2)\end{array}$ & $\begin{array}{l}34 \cdot 3(2 \cdot 5) \ddagger \\
1 \cdot 4(0 \cdot 2) \\
21 \cdot 2(11) \\
2 \cdot 3(0 \cdot 4) \\
0 \cdot 9(0 \cdot 2)\end{array}$ & $\begin{array}{l}40 \cdot 7(0 \cdot 9) \oint \\
1 \cdot 1(0 \cdot 1) \\
8.9(4 \cdot 0) \\
2 \cdot 6(0 \cdot 3) \\
0.5(0 \cdot 1)^{\star}\end{array}$ \\
\hline
\end{tabular}

${ }^{\star} \mathrm{p}<0.001 ; \mathrm{tp}<0.05 ; \ddagger \mathrm{p}<0.02 ; \mathrm{lp}<0.01$ Students $t$ test; values given as mean (SEM).

TABLE V Influence of the restoration of intestinal continuity on serum albumin and acute phase protein concentrations in a control group and patients with Crohn's disease

\begin{tabular}{|c|c|c|c|c|}
\hline & \multicolumn{2}{|l|}{0 Weeks } & \multicolumn{2}{|l|}{12 Weeks } \\
\hline & Control & $\begin{array}{l}\text { Crohn's } \\
\text { disease }\end{array}$ & Control & $\begin{array}{l}\text { Crohn's } \\
\text { disease }\end{array}$ \\
\hline $\begin{array}{l}\text { Albumin }(\mathrm{g} / \mathrm{l}) \\
\alpha_{1} \text { Acid glycoprotein }(\mathrm{g} / \mathrm{l}) \\
\text { C reactive protein }(\mathrm{g} / \mathrm{l}) \\
\alpha_{2} \text { Macroglobulin }(\mathrm{g} / \mathrm{l}) \\
\alpha_{1} \text { Antichymotrypsin }(\mathrm{g} / \mathrm{l})\end{array}$ & $\begin{array}{l}39 \cdot 5(0 \cdot 8) \\
1 \cdot 2(0 \cdot 1 \\
6 \cdot 8(1 \cdot 6) \\
2 \cdot 0(0 \cdot 2) \\
0 \cdot 7(0 \cdot 1)\end{array}$ & $\begin{array}{l}39 \cdot 5(1 \cdot 3) \\
1 \cdot 1(0 \cdot 1 \\
7 \cdot 2(3 \cdot 1) \\
2 \cdot 3(0 \cdot 2) \\
0 \cdot 7(0 \cdot 1)\end{array}$ & $\begin{array}{l}38 \cdot 5(0 \cdot 9) \\
1 \cdot 0(0 \cdot 1) \\
5 \cdot 0(0 \cdot 1) \\
2 \cdot 2(0 \cdot 2) \\
0 \cdot 5(0 \cdot 1)\end{array}$ & $\begin{array}{r}39 \cdot 7(2 \cdot 5) \\
1 \cdot 2(0 \cdot 3) \\
16 \cdot 0(7 \cdot 0) \\
2 \cdot 3(0 \cdot 2) \\
0 \cdot 8(0 \cdot 2)\end{array}$ \\
\hline
\end{tabular}

Values given as mean (SEM).

Figure 2: Effect of faecal diversion and restoration of intestinal continuity on rectal cellular proliferation rates (mean $(S E M))$. $A=$ $p<0.02, B=p<0.05$, paired $\mathrm{t}$ test. $C C P R=$ colonic cellular proliferation rate: other abbreviations as in Figure 1.

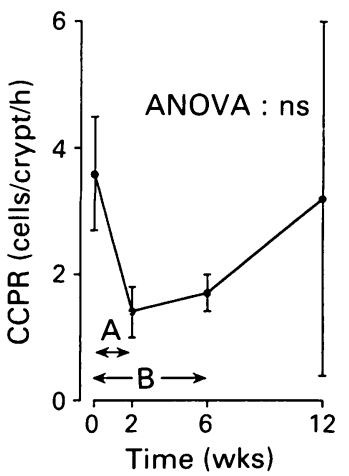

Faecal diversioncontrols activity mean (SEM) (controls $=2 \cdot 60 \quad(3 \cdot 7)$, proctocolitis and epithelial depletion $=23.9$ $(2 \cdot 5)$, proctocolitis and epithelial preservation $=$ $34 \cdot 4(4 \cdot 2), \mathrm{p}<0 \cdot 02)$. Glucosamine synthetase activity in patients with Crohn's colitis and rectal sparing was also significantly greater than controls $(37 \cdot 2(5 \cdot 0), \mathrm{p}<0 \cdot 02)$.

In the control group, faecal diversion failed to produce a significant change in glucosamine synthetase activity (Fig 3). In patients with Crohn's colitis and rectal sparing, glucosamine synthetase activities fell after diversion and remained significanty lower throughout the study period (analysis of variance $\mathrm{p}<0 \cdot 05$ ). In patients with Crohn's proctocolitis, activities were transiently lower two and six weeks after diversion with a return towards normal values at 12 weeks (analysis of variance, NS) (Fig 3). This phenomenon was not associated with a significant change in epithelial cell density. Analysis by a two factor unbalanced hierarchial classification showed a significant difference in the overall trend between the two groups with Crohn's colitis $(p<0.05)$. Restoration of intestinal continuity was associated with a transient increase in glucosamine synthetase activity in both patients with Crohn's colitis and controls. There was no overall significant change by analysis of variance.

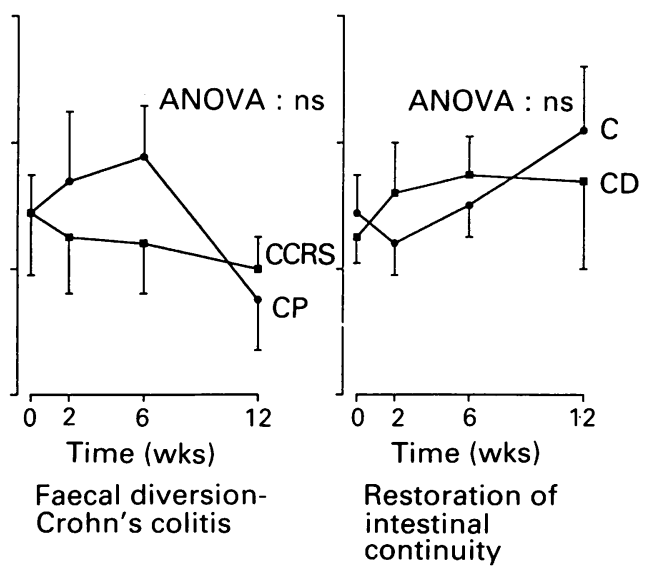

\section{Discussion}

The subjective improvement in both groups of patients with Crohn's colitis after faecal diversion corresponded with a significant fall in the modified disease activity index. The lack of change after restoration of intestinal continuity confirmed the clinical impression of continued disease remission. The relation between disease activity and mucosal inflammation, however, seems tenuous with a poor correlation between disease activity index and macroscopic or histological assessment. ${ }^{25} 30$

Standard peripheral blood indices proved insensitive as markers of colonic inflammation and disease activity. The lack of significant change in haemoglobin values after diversion and restoration of continuity and the poor correlation between the absolute and differential white cell count and disease activity index do not support their use as an indicator of disease activity as previously suggested..$^{213132}$ The erythrocyte sedimentation rate and platelet count have been advocated as the most sensitive laboratory indices of disease activity, $223133-36$ particularly in the presence of active colonic involvement. ${ }^{37}$ Despite a significant increase in the prediversion erythrocyte sedimentation rates and platelet values in patients with Crohn's colitis, there was a poor correlation with the modified activity index concurring with previous reports. ${ }^{34} 3839$ The findings of normal concentrations of serum $\operatorname{IgG}$ and raised $\operatorname{IgM}$ and $\operatorname{IgA}$ concentrations confirm previous studies in Crohn's disease. ${ }^{40-43}$ Their use as activity markers, however, is compounded by the fact that circulating immunoglobulin concentrations may be profoundly influenced by steroid administration, ${ }^{41}$ disease duration, ${ }^{40}$ and changes in nutritional state. ${ }^{44}$

The low preoperative concentrations of serum albumin in patients with Crohn's colitis may reflect disease extent and severity. ${ }^{45}$ The increase after diversion, however, is likely to represent improved nutrition as well as reflect changes in disease activity. ${ }^{22} 32$ The variable acute phase protein response to exclusion and reintroduction of the faecal stream and poor correlation with a disease activity index and histological assessment $^{25}$ do not support the suggestion that serial assessment provides an accurate assessment of clinical state. 363839

The relation between the macroscopic and histological appearance of the colonic mucosa and disease activity remains contentious with clinical remission infrequently mirrored by histological improvement. ${ }^{25} 4647$ This, in part, may represent the focal and transmural nature of the disease although the improvement in the 


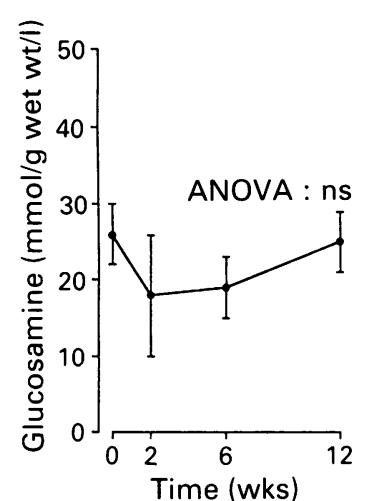

Faecal diversioncontrols

Figure 3: Effect of faecal diversion and restoration of intestinal continuity on rectal glucosamine synthetase $\operatorname{activity}($ mean $(S E M)) . A=$ $p<0.05, B=p<0.01$, paired $\mathrm{t}$ test. Other abbreviations as in Figure 1.

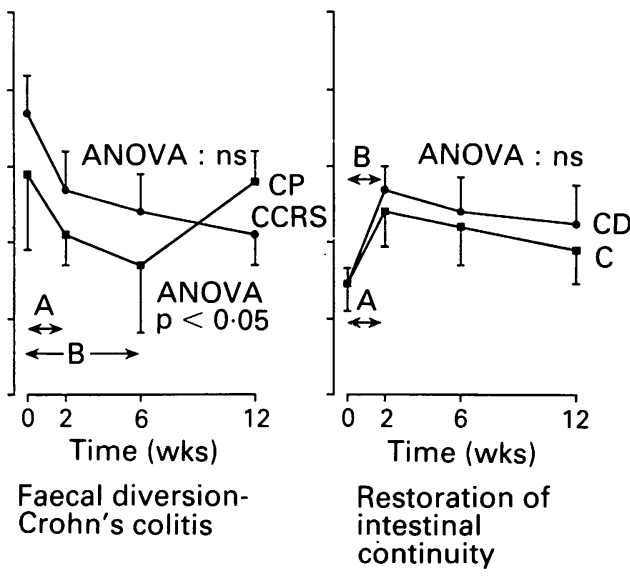

macroscopic appearance of the rectum in patients with proctocolitis suggests that faecal diversion may be associated with some improvement in morphological indices. The deterioration in the macroscopic state of the rectum in the group with Crohn's colitis and rectal sparing after faecal diversion may represent the onset of diversion proctitis. ${ }^{4849}$ This is further supported by the macroscopic improvement in the appearance of the rectum in patients with defunctioned Crohn's colitis after restoration of intestinal continuity because the only diagnostic feature of diversion proctitis is its resolution on reintroducing the faecal stream.

The similarity between the cellular proliferation rates of rectal mucosa in patients with Crohn's colitis, irrespective of the state of the rectum, and the control group is in contrast with the findings in ulcerative colitis where increased rates are found in both remission and relapse. ${ }^{26}$ This, in part, may explain the reduced risk of developing a colitis induced carcinoma in Crohn's disease.

The effect of faecal diversion in the CCPR of the rectum of the control group suggests the faecal stream has a tropic effect on human colonic cellular proliferation. The return to normal values three months after diversion may represent transient homeostatic mechanisms mediated by enterotropic hormones ${ }^{5051}$ as prolonged defunction is reported to be associated with considerable hypoplasia in both $\operatorname{man}^{52}$ and the laboratory animal. ${ }^{535}$

In contrast with the diversion induced hypoplasia of the control group, exclusion of the faecal stream in patients with Crohn's disease had no significant influence on cellular proliferation. This sustained rate of turnover in actively inflamed mucosa may represent an intrinsic defect in cellular homeostatic mechanisms in Crohn's disease or a hyperplastic response to chronic injury with regeneration in the absence of the faecal stream. A similar phenomenon is seen in ulcerative colitis in remission. ${ }^{55}$ The mechanism by which this reactive hyperplasia occurs in unknown. It may occur secondary to reduced cell death or a persistent abnormality in mucosal structure or function after removal of the inflammatory stimuli. The finding of sustained proliferation in macroscopically normal mucosa suggests that the adaptive responses are not dependent on the presence of an overt inflammatory reaction but may occur secondary to the interaction between a faecal constituent and the colonic epithelium.

The lack of change in cellular proliferation on restoration of intestinal continuity is in contrast with the effect of reintroducing the faecal stream in the laboratory animal ${ }^{56}$ and suggests that the reintroduction of enteric luminal contents may not have a significant stimulatory effect on colonic proliferation in man. ${ }^{57}$ In Crohn's colitis such a finding implies that the faecal stream does not have an acute stimulatory effect on colonic cellular proliferation, which would concur with the finding of normal proliferative rates before diversion.

The main protective mechanism of the gastrointestinal epithelium is dependant on the glycocalyx and local mucin production. Mucin, and to a lesser extent immunoglobulin and secretory component, production is reflected by the rate of glycoprotein synthesis. Glucosamine synthetase is the rate limiting step in the biosynthesis of gastrointestinal glycoprotein and thus mucin production. ${ }^{27}$ The significant increase in rectal glucosamine synthetase activity in Crohn's colitis compared with a control group confirms the findings of Goodman $e t a l^{58}$ and suggests that enzymatic changes may represent a sensitive index of intestinal cellular disturbances. It supports the concept that enzyme abnormalities in Crohn's disease may exist without any obvious histological abnormality ${ }^{59}$ and confirms the diffuse nature of the primary abnormality. The reason for increased glycoprotein synthesis in Crohn's disease is unclear. It may represent an inherent abnormality in gastrointestinal mucosa or a protective response to a faecal factor. ${ }^{58}$

The lack of change in rectal glucosamine synthetase activity in the control group after faecal diversion suggests that the presence of faeces in the normal colon has little influence on glycoprotein synthesis and is in keeping with the reported lack of change in other mucosal enzymes after proximal diversion or small bowel resection. ${ }^{60-62}$

The sustained fall in glucosamine synthetase activity after diversion in patients with Crohn's colitis and rectal sparing does not support the concept that there is an inherent abnormality in enzyme activity. It suggests that in Crohn's disease the faecal stream has a strong stimulatory effect on glycoprotein synthesis, even in macroscopically normal tissue. A similar phenomenon is seen in the Crohn's proctocolitis group. The secondary rise that occurs in this group after six weeks corresponds with a similar rise seen in patients recovering from an acute attack of ulcerative colitis ${ }^{58}$ and that seen in rat liver after partial hepatectomy ${ }^{63}$ and may represent a regenerative response.

The transient increase in glucosamine synthetase activity in the control group after restoration of intestinal continuity may represent a normal response to the sudden reintroduction of a large antigenic load or a regenerative response after resolution of defunctioned proctitis which was present in four patients.

The similarity of the response in the Crohn's disease group suggests that any exaggerated response to a faecal constituent is not an acute 
phenomenon but a longterm response to a chronic mucosal insult.

The increase in mucosal glucosamine synthetase activity in patients with Crohn's colitis and the reciprocal changes in colonic cellular proliferation and glycoprotein synthesis after faecal diversion supports the concept that the faecal stream may participate in the inflammatory process. Whether the effect is caused by a single constituent or represents a non-specific inflammatory stimulus is at present unclear. Further assessment of mucosal indices of disease activity with simultaneous instillation of subfractions of ileostomy effluent into the defunctioned colon may help to determine the role of individual faecal constituents in disease pathogenesis.

1 Lee ECG. Split ileostomy in the treatment of Crohn's disease

of the colon. Ann R Coll Surg Engl 1975; 56: 94-102.
2 Harper PH, Truelove SC, Lee ECG, Kettlewell MGW, Jewell DP. Split ileostomy and ileo-colostomy for Crohn's disease of the colon and ulcerative colitis: a 20 year study. Gut 1983; 24: 106-13.

3 Oberhelman HA. The effect of intestinal diversion by ileostomy on Crohn's disease of the colon. In: Weterman IT, Pena As, Booth CC, eds. The management of Crohn's disease. Amsterdam, Oxford: Excerpta Medica, 1976: 216-9.

4 Zelas P, Jagelman DG. Loop ileostomy in the management of Crohn's colitis in the debilitated patient. Ann Surg 1980; 191: 164-8.

5 O'Morain C. Elemental diets in the treatment of Crohn's disease. Proc Nutr Soc 1979; 38: 402-8.

6 Elson CO, Layden TJ, Nemchausky BA, Rosenberg JL, Rosenberg IH. An evaluation of TPN in the management of inflammatory bowel diseases. Dig Dis $S c i$ 1980; 25: 42-8.

7 Weterman IT, Peña AS. The place of split ileostomy in the treatment of Crohn's disease. In: Weterman IT, Peña AS, Booth CC, eds. The management of Crohn's disease. Amsterdam-Oxford: Excerpta Medica, 1976: 224-32.

8 Slater G, Kreel I, Aufses AH. Temporary loop ileostomy in the treatment of Crohn's disease. Ann Surg 1978; 188: 706-9.

9 Burman JH, Thompson H, Cooke WT, Alexander-Williams $\mathrm{J}$. The effect of diversion of intestinal contents on the progress of Crohn's disease of the large bowel. Gut 1971; 12: 11-5.

10 McIllrath DC. Diverting ileostomy or colostomy in the management of Crohn's disease of the colon. Arch Surg 1971; 103: 308-10.

11 Kivel RM, Taylor KB, Oberhelman H. Response to bypass ileostomy in ulcerative colitis and Crohn's disease of the colon. Lancet 1967; ii: 632-6.

12 Allan RN, Cooke WT. Evaluation of metronidazole in the management of Crohn's disease. Gut 1977; 18: A422.

13 Ursing B, Kamme C. Metronidazole for Crohn's disease. Lancet 1975; i: 775-7.

14 Blichfedt P, Blomhoft JP, Myhre E, Gjone E. Metronidazole in Crohn's disease: a double blind crossover clinical trial. Scand F Gastroenterol 1978; 13: 123-7.

15 Ursing B, Alm T, Barany F, Bergelin I, Ganrot-Norlin K, Hoevels $\mathrm{J}$, et al. A comparative study of metronidazole and sulphasalzine for active Crohn's disease: the cooperative Crohn's disease study in Sweden. II results. Gastroenterology 1982; 83: 550-62.

16 Fiocchi C, Parent K, Mitchell P. Proliferative responses of gut mucosal lymphocytes from Crohn's disease patients to enterobacterial common antigen, lipopolysaccharide and cell wall-defective bacteria. In: Pena AS, Weterman IT, cell wall-defective bacteria. In: Pena AS, Weterman IT,
Booth CC, Strober W, eds. Recent advances in Crohn's Booth CC, Strober W, eds. Recent advances in
disease. The Hague: Martinus Nijhoft, 1981: 433-5.

17 Rutgeerts P, Goboes K, Peeters M, Hiele M, Penninckx F, Aerts $R$, et al. Effect of faecal stream diversion on recurrence of CD in the neoterminal ileum. Lancet 1991; 338: 771-4.

18 Rutgeerts P, Peeters M, Hiele M, Kerremans R, Penninckx F Aerts $\mathrm{R}$, et al. A placebo controlled trial of metronidazole for recurrence prevention of Crohn's disease after resection of the terminal ileum. Gastroenterology 1991; 102: A688.

19 Harper PH, Lee ECT, Kettlewell MGW, Bennett MK, Jewell DP. The role of the faecal stream in the maintenance of Crohn's disease. Gut 1985; 26: 279-84.

20 Harper PH. A study of faecal diversion for Crohn's disease of the colon. [Thesis]. Oxford: 1983 .

21 Van Hees PAM, Van Elteren PH, Van Lier HJJ, Van Tan Hees PAM, Van Elteren PH, Van Lier HJJ, Van
Tongeren JHM. An index of inflammatory activity in Tongeren JHM. An index of inflammatory activity
patients with Crohn's disease. Gut 1980; 21: 279-86.

22 Pettit SH, Holbrook IB, Irving MH. Comparison of clinical scores and acute phase proteins in the assessment of acute Crohn's disease. Br f Surg 1985; 72: 1013-6.

23 Johansson SGO, Hogman C, Killander J. Quantitative immunoglobulin determination. Acta Pathologica et Micro biologica Scandinavica 1968; 74: 519-30.

24 Byrjalsen I, Ingwersen SH. Immunoturbidemetry of serum Creactive protein in low concentrations of polythylene glycol. Ann Clin Biochem 1985; 22: 269-72.

25 Gomes P, Boulay C, Smith CL, Holdstock G. Relationship between disease activity indices and colonoscopic findings in patients with colonic inflammatory bowel disease. Gut 1986; 27: $92-5$.
26 Allan A, Bristol JB, Williamson RCN. Crypt cell production rate in ulcerative proctocolitis: differential increments in remission and relapse. Gut 1985; 26: 999-1003.

27 Goodman MJ. Glucosamine synthetase in the human gastrointestinal mucosa in health and disease [thesis]. Oxford: University of Oxford, 1975 .

28 Winterburn PJ, Phelps CF. Purification and some kinetic properties of rat liver glucosamine synthetase. Biochem $\mathscr{f}$ 1971; 121: 701-9.

29 Morgan WTJ, Elson LA. A colorimetric method for the determination of $\mathrm{N}$-acetyl glucosamine and $\mathrm{N}$-acetyl chondrosamine. Biochem $\mathcal{F}$ 1934; 28: 988-95.

30 Prantera $C$, Luizi C, Olivotto $P$, Levenstein S, Cerro $P$, Frances A. Relationship between clinical and laboratory parameters and length of lesion in Crohn's disease of the parameters and length of lesion in Crohn

31 Talsad I, Gjone E. The disease activity index of ulcerative colitis and Crohn's disease. Scand $\mathcal{F}$ Gastroenterol 1976; 11 : colitis and

32 Brignola C, Lanfranchi GA, Campieri M, Bazzocchi G, Devoto M, Boni P, et al. The importance of laboratory parameters in the evaluation of Crohn's disease activity. $\mathcal{F}$ Clin Gastroenterol 1986; 8: 245-8.

33 Harries AD, Fitzsimmons E, Fifield R, Dew MJ, Rhodes J. Platelet count: a simple measure of activity in Crohn's disease. BMF 1983; 296: 1476 .

34 Phillips MS, Bronfield MW. Platelet count in patients with Crohn's disease. $B M \mathcal{F}$ 1983; 286: 1895 .

35 Mee AS, Brown DJ, Jewell DP. Crohn's disease activity index -is it useful? Gut 1978; 19: A990.

36 Andre C, Descos L, Landais P, Fermaman J. Assessment of appropriate laboratory measurements to supplement the appropriate laboratory measurements to supplem
Crohn's disease activity index. Gut 1981;22:571-4.

37 Sachar DB, Smith H, Chan S, Cohen LB, Lichtiger S, Messe J. Erythrocyte sedimentation rate as a measure of clinical activity in inflammatory bowel disease. $\mathcal{F}$ Clin Gastroentero 1986; 8: 647-50

38 Fagan EA, Dyck RF, Maton PNH, Hodgson HJF, Chadwick VS, Petrie A, et al. Serum levels of C-reactive protein in Crohn's disease and ulcerative colitis. Eur f Clin Invest 1982; 12: 351-9.

39 Cooke WT, Prior P. Determining disease activity in inflammatory bowel disease. 7 Clin Gastroenterol 1984; 6: 17-25.

40 Kraft SC, Ford HE, McCleery JL, Kirsner JB. Serum immunoglobulin levels in ulcerative colitis and Crohn's immunoglobulin levels in ulcerative

41 Hodgson HJF, Jewell DP. The humoral immune system in inflammatory bowel disease. II: Immunoglobulin levels. $D i g$ Dis Sci 1978; 23: 123-8.

42 Bolton PM, James SL, Newcombe RG, Whitehead RH, Hughes LE. The immune competence of patients with inflammatory bowel disease. Gut 1974; 15: 213-9.

43 Weeke B, Jasmin S. Serum concentration of 19 serum protein in Crohn's disease and ulcerative colitis. Gut 1971; 12: 297 302.

44 Neumann CG, Lawlor GJ, Stiehm ER, Swendseid ME, Newton C, Herbert J, et al. Immunological responses in malnourished children. Am f Clin Nutr 1975; 28: 89-104.

45 Van Tongerln JH, Eekhout AC. Criteria to assess the severity of Crohn's disease and the effect of treatment. In: Weterman IT, Peña AS, Booth CC, eds. The management of Crohn's disease. Amsterdam-Oxford: Excerpta Medical, 1976: 15360 .

46 Korelitz BI, Sommers SC. Response to drug therapy in Crohn's disease. Evaluation by rectal biopsy and mucosal cell counts. F Clin Gastroenterol 1984; 6: 123-7.

47 Thompson H. Rectal biopsies from the bypassed rectum Archives der Maladies de L'Appareil Digestive et de la Nutrition 1974; 63: 583-41.

48 Glotzer DJ, Glick ME, Goldman H. Proctocolitis and colitis following diversion of the faecal stream. Gastroenterology 1981; 80: 438-41.

49 Korelitz BI, Cheskin LJ, Sohn N, Sommers SC. Proctitis after faecal diversion in Crohn's disease and its elimination with re-anastomosis: implication for surgical management. re-anastomosis: implication for

50 Sagor GL, Ghatei MA, O'Shaughnessy DJ, Al-Mukhtar MYT, Wright NA, Bloom SR. Influence of somatostatin and ombesin on plasma enteroglucagon and cell proliferation after intestinal resection in the rat. Gut 1985; 26: 89-94.

51 Goodlad RA, Lenton W, Ghatei MA, Adrian TE, Bloom SR Wright NA. The effects of an elemental diet, inert bulk and different types of dietary fibre on the response of intestinal ileum to refeeding in the rat and relationship to plasma gastria, enteroglucagon and PYY concentration. Gut 1987; 28: 171-80.

52 Appleton GVN, Williamson RCN. Hypoplasia of the defunctioned rectum. Br f Surg 1989; 76: 787-9.

53 Rijke RPC, Gart R, Langendoen NJ. Epithelial cell kinetics in the descending colon of the rat. II. The effect of experithe descending colon of the rat. 19. The effect of

mental bypass. Virchows Arch [B] 1979; 31: 23-30.
54 Bristol JB, Ghatei MS, Smith JHF, Bloom SR, Williamson

RCN. Elevated plasma enteroglucagon alone fails to alter distal colonic carcinogenesis in rats. Gastroenterology 1987 ; 92: 617-24.

55 Serafini EDP, Kirk AP, Chambers TI. Rate and pattern of epithelial cell proliferatin in ulcerative colitis. Gut 1981; 22: 648-52.

56 Terpstra OT, Dahl EP, Williamson RCN, Ross JS, Malt RA. Colostomy closure promotes cell proliferation and dimethyldrazine induced carcinogenesis in rat distal colon. Gastroenterology 1981; 81: 475-80.

57 Williamson RCN, Bauer FLR, Ross JS, Malt RA. Contribu tion of bile and pancreatic juice to cell proliferation in ilea mucosa. Surgery 1978; 83: 570-6. 
58 Goodman MJ, Kent PW, Truelove SC. Glucosamine synthetase activity of the colonic mucosa in ulcerative colitis and tase activity of the colonic mucosa in
Crohn's disease. Gut 1977; 18: 219-28.

59 Sadikali F. Dipeptidase deficiency and malabsorption of glycyl glycine in disease states. Gut 1971; 12: 276-83

60 Menge H, Grafe M, Lorenz-Meyer H, Riecken EO. The influence of good intake on the development of structural and functional adaptation following ileal resection in the rat. Gut 1975; 43: 731-42.
61 Gleeson MH, Cullen J, Dowling RH. Intestinal structure and function after small bowel bypass in the rat. Clin Sci 1972; 43: $731-42$.

62 Gleeson MH, Dowling RH, Peters TJ. Biochemical changes in intestinal mucosa after experimental small bowel bypass in the rat. Clin Sci 1972; 43; 743-57.

63 Bley RL, Okubo H, Chandler AM. Regulation of glucosamine synthesis in injury and partial hepatectomy. Proc Soc Exp Biol Med 1973; 144: $134-40$. 